Esta publicación cientifica en formato digital es continuidad de la revista impresa ISSN-Versión Impresa 0798-1406 / ISSN-Versión on line 2542-3185Depósito legal pp
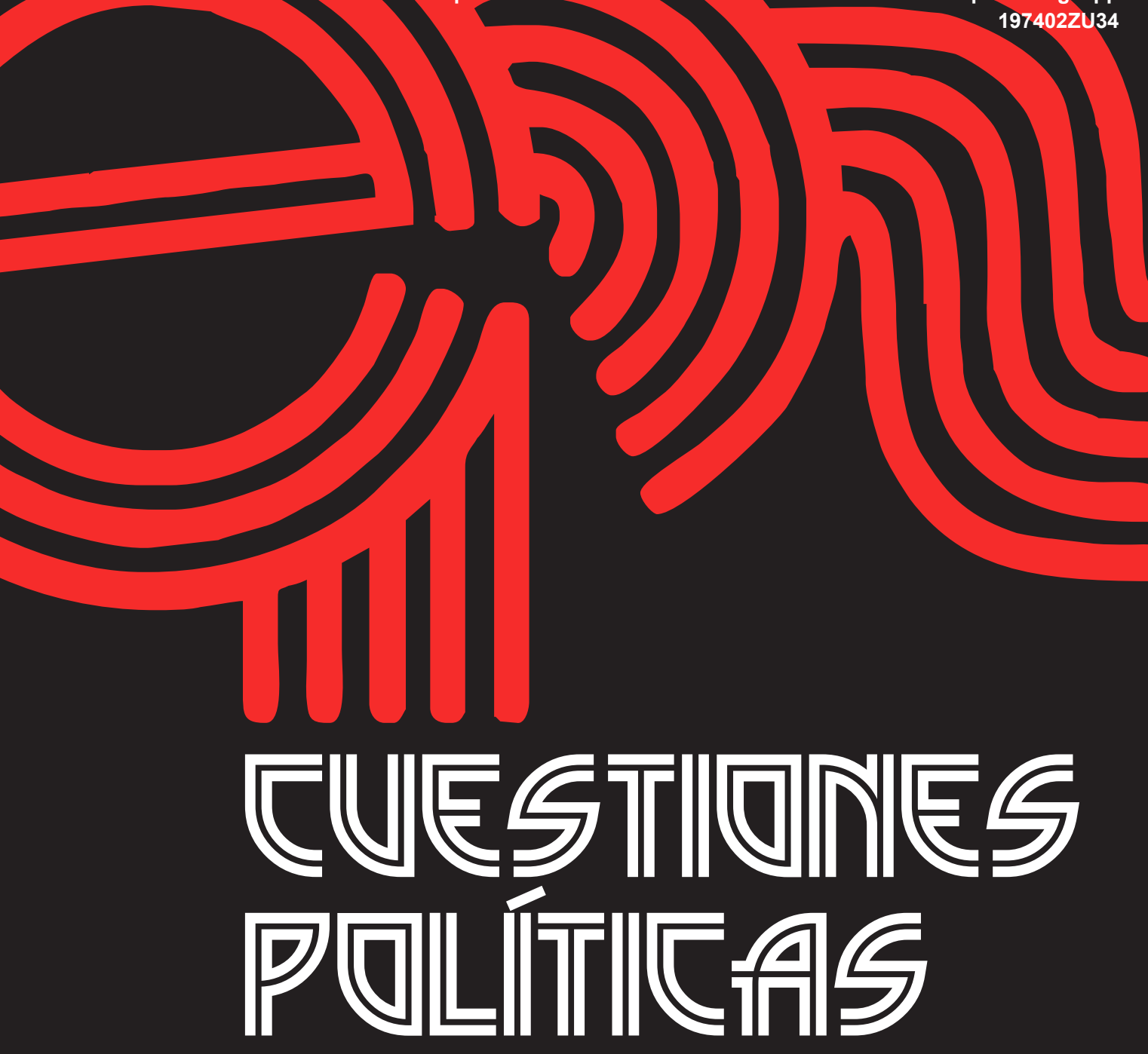

Instituto de Estudios Políticos y Derecho Público "Dr. Humberto J. La Roche" de la Facultad de Ciencias Jurídicas y Políticas de la Universidad del Zulia Maracaibo, Venezuela
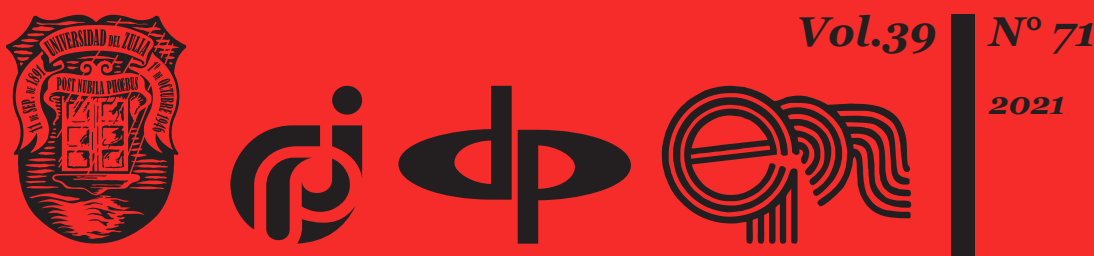


\title{
The Influence of the Coalition Approach in US Policy on the Integration Processes in Europe in the Post-Bipolar Era
}

\author{
DOI: https://doi.org/10.46398/cuestpol.3971.09
}

\author{
Olha Y. Kravchuk * \\ Volodymyr I. Zabolotnyuk ** \\ Yuliia V. Kobets $* * *$ \\ Oksana I. Lypchuk **** \\ Ivanna I. Lomaka $* * * *$
}

\begin{abstract}
The article examines the impact of the coalition approach in US policy on integration processes in Europe in the post-bipolar era. The aim of this article was to identify the peculiarities of the political situation in the world after a period of escalation of the nuclear conflict. It involved an analysis of sources in the field of coalition approach research in the United States, as well as a comparison of its impact on the political situation and European Union law. The author concluded that there is a lack of proper research in the field of the impact of the coalition approach in US policy in the post-bipolar era, and its impact on integration processes in Europe. Comparing the experience of the EU and the US, it was determined that the awareness of nuclear danger affected the development of a coalition approach in US policy. The study resulted in the identified specifics of the EU's security policy under the influence of the US coalition approach, where the need to ensure stability and armed security is crucial. Prospects for further research include identifying US
\end{abstract} influence on Eastern countries.

Keywords: coalition approach; international relations; was post-bipolar; political integration; geopolitics.

* PhD in Political Sciences, Associate Professor, Department of Social and Humanitarian Sciences, Educational and Scientific Humanitarian Institute, Admiral Makarov National University of Shipbuilding, 54025, Mykolayiv, Ukraine. ORCID ID: https://orcid.org/oooo-ooo1-7802-1934

** PhD in History, Deputy Chief of Research of the Land Forces Scientific Center, Hetman Petro Sahaidachnyi National Army Academy, 79026, Lviv, Ukraine. ORCID ID: https://orcid.org/oooo0001-8195-9974

*** PhD in Political Sciences, Associate Professor, Department of Political Institutions and Processes, Faculty of History, Politology and International Relations, Vasyl Stefanyk Precarpathian National University, 76018, Ivano-Frankivsk, Ukraine. ORCID ID: https://orcid.org/oooo-0001-9492-6119

**** PhD in Political Sciences, Associate Professor, Department of Political Science, Faculty of History, Politology and International Relations, Vasyl Stefanyk Precarpathian National University, 76018, Ivano-Frankivsk, Ukraine. ORCID ID: https://orcid.org/oooo-0oo2-1880-6761

**** PhD in Political Sciences, Associate Professor, Department of Political Science, Faculty of History, Politology and International Relations, Vasyl Stefanyk Precarpathian National University, 76018, Ivano-Frankivsk, Ukraine. ORCID ID: https://orcid.org/oooo-0oo2-5616-7016 
Olha Y. Kravchuk, Volodymyr I. Zabolotnyuk, Yuliia V. Kobets, Oksana I. Lypchuk y Ivanna I. Lomaka

\section{La Influencia del Enfoque de Coalición en la Política Estadounidense sobre los procesos de Integración en Europa en la Era Post bipolar}

\section{Resumen}

El artículo examina el impacto del enfoque de coalición en la política estadounidense sobre los procesos de integración en Europa en la era post bipolar. El objetivo de este artículo fue identificar las peculiaridades de la situación política en el mundo después de un período de escalada del conflicto nuclear. Implicó un análisis de fuentes en el campo de la investigación del enfoque de coalición en los Estados Unidos, así como una comparación de su impacto en la situación política y la legislación de la Unión Europea. Se concluyó que hay una falta de investigación adecuada en el campo del impacto del enfoque de coalición en la política estadounidense en la era post bipolar y su impacto en los procesos de integración en Europa. Al comparar la experiencia de la UE y los EE. UU., se determinó que la conciencia del peligro nuclear afectó el desarrollo de un enfoque de coalición en la política estadounidense. El estudio dio como resultado los aspectos específicos identificados de la política de seguridad de la UE bajo la influencia del enfoque de la coalición estadounidense, donde la necesidad de garantizar la estabilidad y la seguridad armada es crucial.

Palabras clave: enfoque de coalición; relaciones internacionales; era post bipolar; integración política; geopolítica.

\section{Introduction}

The topicality of this research is determined by the need to study the political and social reforms in the world (especially Europe and the United States) in the post-bipolar era.

The experience of nuclear confrontation in the era of "bipolarity" was extremely instructive for the world, because there was a threat of brutal and complete destruction of the world at that time. Nuclear arsenals have been and remain a means of achieving the doomsday rather than individual political goals. The theory and practice of international politics faced the problem of involving or integrating these arsenals in world affairs, and the formation of appropriate governance policies (Kononenko, 2018).

After the end of the East-West nuclear conflict, a world political situation arose that failed to find its structure and, therefore, was uncertain.

There was a global tectonic shift in the last decade of the $20^{\text {th }}$ century: the Soviet Union collapsed, leaving the United States a single and truly global 
state, and putting an end to the bipolar world order (Marshania, 2011). However, Western Europe, which has retained much of the world's political and economic power, remains one of the geopolitical heavy-weights. The same applies to other parts of the European continent. Geopolitical changes, which eventually created a new, post-bipolar world order, took place in two stages: the end of the bipolar world order; the first post-socialist states joined NATO and the EU. Accordingly, the global political situation has changed, and there have been numerous international conflicts that pose new challenges for the international community as a whole, as well as for individual countries (Fard, 2019).

After the threat of nuclear war and understanding of the dangers of nuclear potential in the world, new approaches to addressing current political aspects began to take shape. There is a growing number of newly independent states and the growing role of non-state actors, growing interdependence, changing relationship between economic and military factors as the most typical features of the world.

Coalition approaches to solving the set objectives have become important.

In the 90's of the 20th century, international relations underwent extraordinary transformations. The post-bipolar period was characterized not only by structural changes, but also by radical new circumstances in the challenges of international security at all levels, as well as the reorientation of foreign policy of leading states, ideological changes and revision of international regimes and organizations. At the same time, NATO was considered the only organization that was able to take responsibility for the state of international security in the Euro-Atlantic area (Volodina, 2012).

The corresponding path of NATO reform was determined not only by the positions of the leading member States, primarily the United States and the United Kingdom, but also by changing international security conditions, transforming challenges and identifying new sources of danger. It was emphasized during the NATO Summit in London on 5-6 July 1990 that Europe had never had such a realistic opportunity to overcome the constant recurrence of war and peace. This motif of the summit coincided with the strategic vision of the situation by leading NATO member States, in particular the United Kingdom. The agenda included consideration of the basic principles of regional security in the conditions that have changed radically as a result of the fall of the Berlin Wall, radical changes in the foreign policy of the Soviet Union, including in US-Soviet relations. The Summit participants had a double task: on the one hand, it was necessary to formulate a new vision of security principles in Europe; and, on the other hand, to transform NATO itself so that it best adapts to such principles. 
Olha Y. Kravchuk, Volodymyr I. Zabolotnyuk, Yuliia V. Kobets, Oksana I. Lypchuk y Ivanna I. Lomaka

190

The Influence of the Coalition Approach in US Policy on the Integration Processes in Europe in the Post-Bipolar Era

The solution to the first problem was found in the spread of cooperation between all European countries, the final overcoming of political differences and the practical implementation of the concept of indivisible security when the security of any country is impossible if its neighbours remain in danger (Volodina, 2012). The Summit resulted in the provisions of the London Declaration on a Transformed North Atlantic Alliance.

This document reaffirmed the US commitment to maintaining European security in the new environment, a position that best suits the long-term interests and strategic vision of the United States and the United Kingdom. Among other things, the declaration notes NATO's readiness to engage in dialogue with the Soviet Union and set new standards of openness in Europe - all this evidenced a radical change in the geopolitical situation on the continent (Volodina, 2012).

A new military strategy has been adopted, moving from a border defence strategy to a flexible response doctrine.

Accordingly, this period was determined by the achievement of consensus in the following areas:

- deployment of fewer regular forces at the borders.

- gradual reduction of combat readiness of its units, reduction of the need for combat training and the number of exercises.

- setting limits on the level of nuclear forces needed to prevent war; etc. (Volodina, 2012).

The issue of the impact of the collision approach in the post-bipolar era remains problematic today. This problem is becoming particularly acute, especially due to the change in foreign policy orientations in the world. It is these factors that determine the topicality of this research.

The aim of the article is to analyse US policy in the post-bipolar era, and its further impact on the formation of EU security policy.

This aim involves the following objectives:

- determine the place of the United States in the post-bipolar era on the world scene.

- analyse EU measures under the influence of US coalition policy.

- determine the main results of the post-bipolar era in the international arena. 


\section{Methods and Materials}

This article uses general scientific and legal research methods, which include the comparative legal method used to conduct a comprehensive analysis of the conflict approach in the United States in the post-bipolar era. The comparative legal method allowed analysing the practice and standards of the European Union and other foreign countries in this area.

The paper also used historical method to study and analyse the preconditions for the creation of coalition approaches and their impact on the EU. These methods allowed analysing the political situation and practical achievements in different periods of the post-bipolar era.

Ukrainian and foreign scientific and practical materials on the research topic are analysed. Among the sources studied, we selected works that allowed us to investigate the history of the conflict approach in the United States.

An analysis of the legislation of individual EU and US countries in this area was also carried out. Accordingly, an analysis of international legislation, international documents and acts in this area was conducted.

The research procedure provided for determining the relevance and urgency of the chosen topic for research, analysis of scientific and practical methods and approaches used to conduct research on the impact of the coalition approach in US policy on integration processes in Europe in the post-bipolar era.

The next stage included the selection of materials for the study on the basis of an integrated approach, which allowed a comprehensive study of the subject, as well as identify the main problems and prospects of this study. We also selected materials according to the territoriality criterion, which allowed determining the state of development of this problem in different regions and to study the EU experience. As a result, we have drawn conclusions and provided recommendations on the basis of the research. An important task is to study the impact of the coalition approach in US policy on integration processes in Europe in the post-bipolar era.

The object of the research is public relations in the post-bipolar era in the development of the coalition approach in US policy, and their impact on integration processes in Europe.

\section{Results}

Analysis of research has shown that the world political situation of the "post-bipolar" world carried the prospect of "New Middle Ages", as it 
Olha Y. Kravchuk, Volodymyr I. Zabolotnyuk, Yuliia V. Kobets, Oksana I. Lypchuk y Ivanna I. Lomaka

characterized by the weakening of state institution and the emergence of various social organizations, and later - the emergence of various lowintensity conflicts with nuclear challenges between them (Kononenko, 2018:54).

Accordingly, the creation of the EU has become a remarkable fact. The European Union was created on the basis of the Treaty of Rome, signed on 25 March 1957 by Belgium, Italy, Luxembourg, the Netherlands, Germany and France. Denmark, Ireland, and the United Kingdom joined these countries in 1973, Greece in 1981, Spain and Portugal in 1986, Austria, Finland and Sweden - in 1995. Negotiations on Norway's accession to the EU were successful, but $52.5 \%$ of Norwegians who took part in the national referendum on 27-28 November 1994 voted against EU membership. After the last enlargement, Estonia, Cyprus, Latvia, Lithuania, Malta, Poland, Slovakia, Slovenia, Hungary, the Czech Republic joined the EU in 2004, followed by Bulgaria and Romania in 2007.

At a meeting of the European Council held in Maastricht on 9-10 December 1991, the Heads of states and governments of the European Community concluded the Treaty on Political, Economic and Monetary Union, which together constitute the Treaty on European Union. The Treaty entered into force on November 1, 1993, upon its classification by all parties.

On 15-16 June 1997, the heads of states and governments of the EU Member States adopted a number of amendments to the Maastricht Treaty on the future common foreign and security policy (European Union, 2012).

In accordance with the Maastricht Treaty, the Contracting Parties were to create the European Union among themselves, which marks a new stage in development. It is a process of creating an ever-closer union between the peoples of Europe, in which decisions are made as openly as possible and as close as possible to the citizens. The Union is based on the European Communities, complemented by the policies and forms of cooperation established by the Treaty. Its task is to arrange relations between Member States and between their peoples, demonstrating consistency and solidarity (Ventura et al., 2006).

In general, the European Union is an international entity with a global reach, but has a number of special characteristics compared to government agencies. The European Union is as an international actor at regional and global levels. Its relevant policies are aimed at securing the interests and developing the capabilities of member states. And the peculiarities of the EU structure affect the quality and capabilities of the EU as a subject of international security. Specific issues facing the EU include the diversity and difference of its institutions and Member States, the coherence and effectiveness of its external action, as well as issues of internal and external legitimacy. 
In recent years, the EU has become an important player in international security policy. In the past, EU peacekeeping missions have been designed to prevent the recurrence of negative scenarios in European history. That is why the EU has become a defender of liberal values and the international legal order.

Over the last forty years, all EU countries have participated in European regional security partnerships, peacekeeping operations and arms control agreements, and adapted their security policies to these instruments.

After the end of the Cold War and the disbandment of the Warsaw Pact, the choice of new security instruments contributed to the development of EU security and defence policy. This has forced the EU to reconsider its priorities and course of development.

Together, the new common security and defence policy, after a brilliant and promising start in the first decade of the $20^{\text {th }}$ century, as evidenced by the large number of militaries, civilian and mixed operations in the rest of the world to reduce conflict and resolve crises, has reduced and almost lost control of multilateralism of international security management.

The role of the European Union in international relations goes far beyond the positions and actions of the Common Foreign and Security Policy. The EU is also the largest player in world trade. It is also the largest financial donor to developing countries and one of the largest to the Middle East. Besides, the European Union provides the largest funding for international efforts to create the conditions for lasting peace in the former Yugoslavia. Many other areas of European Union policy, such as agriculture and fisheries, also have an important external dimension. The EU's role in external relations will be further strengthened after the creation of the European Economic and Monetary Union and the introduction of the single currency (Rudko, 2012).

The European Union pays great attention to ensuring that the Common Foreign and Security Policy is consistent with all other aspects of the EU's foreign policy. Both the Council of Ministers and the European Commission are responsible for the compatibility of the Union's overall external action with the objectives of external relations, security, economics and development policy.

The large-scale reforms that began in the USSR in the second half of the 1980 's led to the intensification of similar processes in the Soviet-oriented socialist countries, and later to the disintegration of the entire Soviet Union. "Eastern Bloc". The issue of finding a new place in the system of international relations, which arose before all former allies of the USSR with the onset of the post-bipolar period, was particularly relevant for Mongolia (Ignatov, 2020). In this country, where a peaceful transition to democracy took place in 1990, a serious economic crisis soon began, caused by the 
Olha Y. Kravchuk, Volodymyr I. Zabolotnyuk, Yuliia V. Kobets, Oksana I. Lypchuk y Ivanna I. Lomaka

The Influence of the Coalition Approach in US Policy on the Integration Processes in Europe in the Post-Bipolar Era

cessation of large-scale Soviet economic aid, as well as the need for further political reforms and the transition from economics to market tracks.

The last decade of the 2oth century was marked by the triumph of the United States, which after the collapse of the Soviet Union were not only the only superpower, but also a determining factor in the formation of a new world order.

First of all, it should be noted that the global dominance of the United States was based on the willingness of the ruling circles of most of the country to pursue neoliberal economic policies, which included privatization of the public sector, liquidation of the welfare state, reduction of wages for the sake of "competitiveness", opening borders for foreign goods and capital, lifting any restrictions on financial speculation. The world economic order a priori provided for US hegemony in the military, political, technological, socio-cultural and information dimensions.

At that time, a policy was taken to comprehensively strengthen relations during the preparations for the Gulf War. Traditionally, Anglo-American relations have received a new impetus in times of international crises and military conflicts. It was in these situations that the particular closeness of the partners was confirmed, and it became clear that other countries were unable to provide the United States with a level of support comparable to that of the United Kingdom. London was determined to share the burden of global responsibility with its foreign partner.

During the Gulf War in January 1991, Great Britain and the United States closely coordinated their diplomatic missions to put pressure on NATO, EU, and WEU allies to encourage them to participate more actively in the multilateral coalition. Great Britain has a negative view of the idea of holding EU talks with Iraq without US involvement, and of France's attempts to take independent steps to resolve the conflict. London's tough stance on resolving the crisis was strongly supported by the United States and influenced the allies in the "right direction" (Rudko, 2012).

Great Britain's military contribution to the Gulf War was the largest among the largest Western countries since the United States. It was the British Armed Forces that became Washington's main combat partner in Operation Desert Storm. British troops were fully integrated with the Americans and operated under their leadership (Rudko, 2012).

The intensity of Anglo-American contacts continued to remain high after the end of hostilities.

Almost all countries in the Euro-Atlantic community also had to focus on their modernization and development in the United States, especially in order to adapt their government institutions that had been formed in the course of their own history to American domestic and foreign policy 
standards. However, the process had its temporal and spatial (geopolitical) limitations.

The scale of change that swept the world in the late 2oth century is associated with the phenomenon of globalization. The introduction of a set of unification processes, the establishment of universal structures, ties and relations, globalization manifested itself in the transition of dominance in politics and economics to supranational institutions (UN, NATO, G-7, Washington Consensus) and transnational corporations, and in the cultural sphere - in the global expansion of common standards of mass culture and individualized lifestyle, which replace traditional culture (Fesenko, 2017).

There is a view that current US security strategies are built around integration policies, which encourage the states, through a series of measures, to agree on worldviews (Bialasiewicz et al., 2007).

In general, the very concept of the state as the highest form of political organization has undergone tremendous changes in the post-bipolar era, which proved its vulnerability to transnational penetration; the relationship of internal forces; as well as international regimes, laws and organizations. The concept of sovereignty has been called into question by the United Nations Secretaries-General themselves. At the same time, the state relied on more aspects of human activity than ever before, including protection from external threats and destabilizers. Extreme forms of authoritarian order, such as apartheid systems in the third world and totalitarian systems in the second world, gave way to institutional participation, which was unable to maintain order. Some states end up with such a high degree of concentration of power that they have reached the peak of internal conflict.

Moreover, conflict is not necessarily chaos, just as disorder is the opposite of any particular form of order (Piren, 2000). Order manifests itself in many, often supposedly opposite forms: conflict and cooperation, war and peace, freedom and security, oppression and justice, symmetry and asymmetry, and many other concepts and values contained in sections of this collection.

The analysis reveals the main norms of factors among people who are actively involved in conflicts: future fears and concerns of the community, as well as distrust of stakeholders. So, conflicts indicate a deeper discourse in the discussion, thus indicating the diversity of motivations, values and beliefs, and indicating the inadequacy of relying on a lack of knowledge and/or explanations about the fractionation of policy (McLaughlin and Cutts, 2018). Moreover, order is what allows you to research and analyse any subject, because it turns data into knowledge; science seeks patterns or orders in events so that the theory can serve "to introduce order and meaning into a mass of phenomena that would otherwise remain disconnected and incomprehensible" (Zartman, 2009: 290). 
Olha Y. Kravchuk, Volodymyr I. Zabolotnyuk, Yuliia V. Kobets, Oksana I. Lypchuk y Ivanna I. Lomaka

196

The Influence of the Coalition Approach in US Policy on the Integration Processes in Europe in the Post-Bipolar Era

Accordingly, the coalition's tactical environment was to consist of different networks of two or more organizations that team up to conduct a short-term tactical operation with a clearly defined mission. Today, cybersecurity is an important factor in the work of the coalition. This is a complex challenge due to the need for operational efficiency combined with the limited relationship of trust that exists between the various coalition partners. New paradigms in networks, such as programme-defined networks, provide a mechanism for more effective solutions to security problems in a coalition (Mishra et al., 2017).

Since the beginning of the post-bipolar era, the conflict has escalated, and new solutions have been sought. Agreed arrangements have been the subject of a huge surge of attention and analysis in the last decades of the previous millennium. Negotiations have been described as involving "an initial rift - a dispute - and an attempt to reach an order - a settlement." Today, this is being studied in an uninstitutionalized order of international relations, leaving the coalition, the government, and their variants as contradictory systems of order for domestic policy. While in the real world there are signal dates for a new focus on negotiations, in the 1960's in international relations, when the Cuban missile crisis turned the military confrontation of the superpowers into a diplomatic bargain, and in 1968 in domestic relations, when young people around the world relinquished power tried to agree on new realities. It was also a time of fundamental work, which initiated the analysis of the form of order, which differs from others - neither ordered nor divided, but based on unanimity between formally equal parties on the result.

Previous agreements and contracts had the legitimacy of participation and ownership, shared with the voted orders, but without the necessary players, and the triple choice of negotiated order (accept, reject, extend) allows getting a positive amount of creativity, which provides double choice of voting and "no choice" that is, such decisions did not provide for assuming the power. However, the negotiations required recognition of the legitimacy of the parties and tolerance for ambiguity in decisions that some situations did not allow at the time. Without negotiation analysis tools, it would be impossible to explore many aspects of the global and domestic order, such as international regimes, labour relations, peacekeeping, business agreements and law-making, but it is important that much remains to be done and learned about negotiations (Zartman, 2009).

Thus, the negotiations of that time can be considered as a dependent and as an independent variable in the search for order. Negotiation processes were conducted according to one of three models (or their combination): distributive bargaining for concessions; compensatory exchange trading, which gives positive results or a design that integrates parts, which also gives a positive result. At the same time, in fact, there was a high correlation 
between the process and the result, but the determinants of the initial choice are not yet clear.

Accordingly, the trajectory of social security reforms in the United Kingdom and the United States after 2010 continued to reflect common views on the different characteristics of US and British policy styles. In particular, the gap in the traditional view of the stark contrast between the tough, competitive, and conflicting style in the US and the flexible policy style in the UK and the EU, guided by consensus, is still useful to describe the latest reform paths in both countries. Empirical analysis shows that the traditional confrontation between the highly politicized, rigid and limited regulatory style in the US versus the flexible regulatory process that dominates the EU, with little scope for parliamentary scrutiny and legal challenges in the UK remains broadly accurate. In the UK, Conservativeled coalition governments after 2010 could ignore resistance to cumulative, essentially punitive changes to social security reform in the context of strengthening public attitudes towards welfare recipients by adopting a package of regulations with very little parliamentary scrutiny and limited judicial scrutiny. In the United States, administrative exemptions, when a federal administrative body waives legal requirements, have become the main policy tools to try to make policy changes, but the use of bylaws has become open to political and legal issues (Daguerre, 2020).

\section{Discussion}

The complexity of the study is due to the peculiarities of socio-political changes, but after the terrorist attacks of September 11, 2001, the escalation of the civil war in Syria, escalating conflict in Ukraine, prolonged chaos in the Middle East, the emergence of Islamic State, the crisis in the EU begins to change. Largely due to the above events, the geopolitical world order is in transition (Fard, 2019).

There are currently several approaches to the political situation in the world in international relations: realism, liberalism, Marxism, behaviouralist are among the main prospects in international relations. In the light of the collapse of the Soviet Union and the subsequent withdrawal of Soviet troops from Central Europe, the debate between neorealism and neoliberal institutionalism became relevant. Realism and neorealism, as well as to some extent neoliberalism, have also had a profound effect on US foreign policy (Moravcsik, 1997; Slaughter, 2004). Neorealists dominate the world of security research, while neoliberals focus on political economy and, more recently, on issues such as human rights and the environment. These theories do not offer sharply contrasting images of the world. Neorealists say they are worried about survival. They argue that neoliberals are overly 
Olha Y. Kravchuk, Volodymyr I. Zabolotnyuk, Yuliia V. Kobets, Oksana I. Lypchuk y Ivanna I. Lomaka

optimistic about opportunities for cooperation between states. Neoliberals face claims that all states have common interests and can benefit from cooperation (Martin and Simmons, 1998).

The processes of globalization have forced neorealists and neoliberals to consider such problems and address new challenges to the international order (Ogunbanjo, 2021).

The United States ranks high on the scale of most traditional power factors, and more importantly, it continues to be able to shape and control the scale and scope of international influence of all other major players within the modern global international system. The relative decline in US influence on world politics at the beginning of the new millennium was in fact offset by a profound change in the nature of American power, which is now taking the form of structural dominance. It is thought that US hegemony is not doomed to weaken, given the enormous economic, political, and intellectual influence that the United States has already had on international relations since World War II (Subotin, 2019). The continued role of the United States in $21^{\text {st }}$-century international politics depends on the ability of the US political class to adapt to and use the social power of the many non-state international actors who must control the leading role in future world politics (Ferguson, 2008).

Accordingly, the unification of states in international organizations (UN, NATO) began to play a significant role in the political coalition component.

Next, the dynamics between informal groups of states and the UN Security Council are determined. Informal groups are thought to have spread in response to systemic change (Baccarini, 2018). These groups serve as a mechanism to overcome the structural constraints of the Security Council and to voice stakeholders in the conflict. In essence, they can reduce the gap in the involvement of participants, which grows out of many aspects of international conflicts, which prevents the Council from formulating an effective response to crisis situations. The processes of resolving diplomatic problems and their collective legitimacy are also becoming increasingly fragmented. Some are usually delegated to informal groups or coalitions of states, while the UN Security Council provides the latter (Subotin, 2019).

Thus, two decades after the end of the Cold War, the system of international relations has undergone some changes, and tangible results can be identified (Prantl, 2005). At the global level, there has been a transition from bipolarity to multipolar stability, mainly due to US dominance and consensus of countries with great influence in international organizations (UN, G8, G20) on the foundations of the political situation in the world (Prantl, 2005).

So, we believe that the need to ensure the security of the world community has become a significant aspect of foreign policy in the post- 
bipolar era. Accordingly, the US coalition approach has become key to reaching consensus in resolving global conflicts (Majinge, 2011).

This was the result of a certain configuration of hierarchy and power, or, in other words, the balance of power and its recognition by international actors. In the early 1990's, the world's leading nations recognized the dominance of the United States and placed heavy and costly responsibility on the United States for its role as a global policeman. However, due to constant changes, this new world order proved to be unstable, and therefore at the beginning of the 21st century there were active attempts to revise it (Glebov, 2014).

There is still scientific debate as to whether the United States will lose its position as a world leader (Brooks

and Wohlforth, 2014). Most scholars argue that the United States will not soon lose its leadership position; rather, it faces a twenty-year window of opportunity to change the international system. Europe, in turn, has always been open to the rest of the world. The EU has never been a clearly demarcated continent or a fixed limited entity, and it has always been characterized by a change in policy space (Glebov, 2019). Unlike the United States or the East Asian perspective, the European perspective uses a critical approach to traditional divisions. The author demonstrates the added value of the European approach to international relations, given both the shortcomings and achievements in European history and modern European unity (Telò, 2010).

Thus, at one time bipolar system supports an increase in military capabilities with a high probability of its use, regardless of the consequences (Vakarchuk, 2018). The purpose of the post-bipolar phenomenon is not to increase, but to improve for the sake of protection. The post-bipolar system is still evolving, and this option is possible given the current trend that we will return to realism with several stages of protection of state security at the state level, at the organizational level, at the regional and general level of support.

In general, the bipolar system was created by the emergence of two powerful military-political blocs, for which the European continent became a springboard for an aggressive policy towards each other. The post-bipolar system was formed, on the contrary, due to the disappearance of the warring party, which in fact means the absence of a direct threat, as well as lack of pressure and control, which caused lawlessness in a certain area and leads to new threats - regional armed conflicts, escalation of Nagorno-Karabakh conflict). That is, the conditions under which they were created, and hence the mechanisms of provision, are completely different.

In the early 1990's, when the United States played the dominant role in solving global problems, a post-bipolar system of international relations was 
Olha Y. Kravchuk, Volodymyr I. Zabolotnyuk, Yuliia V. Kobets, Oksana I. Lypchuk y Ivanna I. Lomaka

being formed. It is in this decade that NATO's new identity - one of the key themes of this chapter - is gradually manifested and consolidated (Weible and Jenkins-Smith, 2016). Like other international organizations (IOs), the North Atlantic Treaty Organization (NATO) has become more complex since 1990. In the following summary reports, this collection examines the bureaucracy and decision-making process of NATO since the end of the Cold War, identifies changes in it, and assesses their implications for external security and related changes in governance - changes in national security policy transformation (Flockhart, 2014).

So, even when scholars have declared the end of the bipolar era, there is still a moment of primacy in the United States, and scholars are still trying to understand the exact nature of the primacy of the United States (Mayer, 2014).

Accordingly, the coalition approach has become expedient in the conditions of need to achieve a sustainable political solution and security results, even by rigid methods.

\section{Conclusions}

As a result of the study, we can conclude about the urgency of this subject in the world. New geopolitical challenges following the collapse of the bipolar system of international relations have led to a new balance of powers in the region and changes in foreign policy.

Since the emergence of public policy as a field of research in the middle of the $2 \mathrm{O}^{\text {th }}$ century, the final problem has been the development of theoretical approaches for the comparative study of political processes. One of the theoretical approaches that has survived for a long time is the Coalition Framework. With more than three decades of research and hundreds of applications spanning the globe, coalition approaches are now one of the most established and widely used approaches to studying political processes.

So, international organizations such as NATO have played a special role in shaping the coalition approach.

In general, since then societies (USA, Canada, Great Britain, Germany, France, Italy, Australia, etc.) are characterized by a community of strategic foreign policy and foreign economic goals, which is associated with the integration of globalization into political, economic, military, security, social science and the humanities. In turn, most regional states depend on the geopolitical world centres (USA, China, EU countries, Russia) of the system of international relations. Regional states are forced to cede their national sovereignty to the financial and economic expansion of the world's leading 
states in order to ensure national stability, security and development in the face of global conflicts. This factor determines the geopolitical unification of regional states around these advanced countries, as well as the formation of a common foreign policy to ensure the interests of the international arena.

Accordingly, the problem of ensuring security by the US remains relevant today.

Let us note that the negotiations of that time can be considered as an independent variable in the search for order in the world. Negotiation processes were conducted according to one of the three models and were based on the motives of finding a balance between the interests of the parties and reaching an agreement. At the same time, there was actually a strong correlation between the process and the result, but the determinants of the initial choice are not yet clear. Decentralization and more or less consistent development have been and remain reasonable and important tasks of international cooperation. Today, the decentralization of economic development has become one of the pillars of sustainable development, which means that the economic development of any region is a global task that affects all humanity.

The European Union is currently working to build a security alliance that will make Europe safer by stepping up the fight against terrorism and serious crime, as well as strengthening Europe's external borders.

The EU offers its citizens a territory of freedom, security, and justice without internal borders. The overall goal of the security union is to increase security within the European Union. The EU and its Member States work together to combat terrorism and brutal radicalization, serious crime, organized crime and cybercrime. Therefore, we can conclude that the EU plays a significant strategic role in world security policy. At the same time, it should be noted that the category of security has expanded significantly in recent years, which contributed to a different understanding of the role and importance of the EU in security policy.

\section{Bibliographic References}

BACCARINI, Mariana Pimenta Oliveira. 2018. "Informal reform of the United Nations security council” In: Contexto Internacional. Vol. 40, No. 1, pp. 97-115.

BIALASIEWICZ, Luiza; CAMPBELL, David; ELDEN, Stuart; GRAHAM, Stephen; JEFFREY, Alex; WILLIAMS, Alison J. 2007. "Performing security: the imaginative geography of current US strategy" In: Political Geography Vol. 26, pp. 405-422. 
Olha Y. Kravchuk, Volodymyr I. Zabolotnyuk, Yuliia V. Kobets, Oksana I. Lypchuk y Ivanna I. Lomaka the Post-Bipolar Era

BROOKS, Stephen G; WOHLFORTH, William C. 2008. World Out of Balance: International Relations and the Challenge of American Primacy. Princeton University Press. Princeton, USA.

DAGUERRE, Anne. 2020. "Policy styles and welfare reform in Britain and the USA: The conservative-led coalition government and the Obama administration compared" In: Journal of Social Security Law. Vol. 27, No. 3, pp. 130-158.

EUROPEAN UNION. 2012. Consolidated versions of the Treaty on European Union and the Treaty on the Functioning of the European Union 2012/C 326/. Available online. In: https://eur-lex.europa.eu/legal-content/EN/ TXT/?uri=celex\%3A12012M\%2FTXT. Consultation date: 28/01/2021.

FARD, Rebin. 2019. "The new foreign policy pendulum: Geopolitical codes of German foreign policy in the post bipolar world order" In: Politics in Central Europe. Vol. 15, No. 3, pp. 383 $\square-418$.

FERGUSON, Yale H. 2008. "Approaches to defining "empire” and characterizing United States influence in the contemporary world" In: International Studies Perspectives. Vol. 9, No. 3, pp. 272-280.

FESENKO, Mykola Vasylyovych. 2017. "Phenomenon of postglobalization in the context of a new international order formation” In: Bulletin of Mariupol State University. Series: History. Political Studies. Vol. 19, pp. 266-274.

FLOCKHART, Trine. 2014. Post-bipolar challenges. New visions and new activities. In: Sebastian Mayer (Ed.), NATO's Post-Cold War Politics: NATO's Post-Cold War Politics. New Security Challenges Series (pp. 7188). Palgrave Macmillan. London, UK.

GLEBOV, Sergiy. 2014. The beginning of Ukraine and the end of the postbipolar world. In: Viktor Stepanenko and Yaroslav Pylynskyi (Eds.) Ukraine after Euromaidan: Challenges and Hopes (pp. 105-114). Peter Lang. Bern, Switzerland.

GLEBOV, Sergiy. 2019. The EU's policy of integration in the context of European regionalization. Olga Brusylovska, and Igor Koval, (Eds.), Prospects of Development in EU Politics: Global and Regional Dimentions (pp. 2032). Odesa Mechnikov National University Press. Odesa, Ukraine.

IGNATOV, Ivan Alekseevich. 2020. "Japanese-Mongolian relations in the postbipolar period within the context of Mongolia's "third neighbor" policy" In: Japanese Studies in Russia. Vol. 1, pp. 69-84.

KONONENKO, Serhiy Volodymyrovych, 2018. "The war in the international politics: technology, culture, organizing” In: Scientific Notes of the Kuras 
Institute of Political and Ethnic Studies of the National Academy of Sciences of Ukraine. Vol. 41, pp. 53-63.

MAJINGE, Charles Riziki. 2011. "Regional arrangements and the maintenance of international peace and security: the role of the African Union peace and security council" In: Canadian Yearbook of International Law. Vol. 48, pp. 97-149.

MARSHANIA, Zurab. 2011. "The phenomenon of post-bipolar regionalism in Europe" In: The Caucasus \& Globalization. Vol. 5, No. 1-2, pp. 23-34.

MARTIN, Lisa L; SIMMONS, Beth A. 1998. "Theories and empirical studies of international institutions" In: International Organization. Vol. 52, No. 4, pp. 729-757.

MAYER, Sebastian. 2014. Introduction: NATO as an organization and bureaucracy. In: Sebastian Mayer (Ed.), NATO's Post-Cold War Politics. New Security Challenges Series (pp. 1-27). Palgrave Macmillan. London, UK.

MCLAUGHLIN, Danielle M; CUTTS, Bethany B. 2018. "Neither knowledge deficit nor NIMBY: Understanding opposition to hydraulic fracturing as a nuanced coalition in Westmoreland County, Pennsylvania (USA)" In: Environmental Management. Vol. 62, pp. 305-322.

MISHRA, Vinod K; VERMA, Dinesh C; WILLIAMS, Christopher. 2017 Improving security in coalition tactical environments using an SDN approach. In: Shao Ying Zhu, Sandra Scott-Hayward, Ludovic Jacquin and Richard Hill (Eds.), Guide to Security in SDN and NFV. Computer Communications and Networks (pp 273-298). Springer. Cham.

MORAVCSIK, Andrew. 1997. "Taking preferences seriously: a liberal theory of international politics" In: International Organization. Vol. 51, No. 4, pp. 513-553.

OGUNBANJO, Martin Abimbola. 2021. "Neo-realism and neo-liberalism in global politics: towards assessing the intellectual siblings" In: KIU Journal of Social Sciences, Suppl. 1, Vol. 7, No. 2, pp. 57-76.

PIREN, Mariya Ivanivna. 2000. Conflict and Management Roles. SocioPsychological Analysis. Interregional Academy of Personnel Management. Kyiv, Ukraine.

PRANTL, Jochen. 2005. "Informal groups of states and the UN security council" In: International Organization. Vol. 59, No. 3, pp. 559-592. 
Olha Y. Kravchuk, Volodymyr I. Zabolotnyuk, Yuliia V. Kobets, Oksana I. Lypchuk y Ivanna I. Lomaka

RUDKO, Serhiy Oleksiyovych. 2012. Foreign Policy of Western European Countries during Post-Bipolar Period. Textbook for the Course. Publishing House of Ostroh Academy National University. Ostroh, Ukraine.

SLAUGHTER, Anne-Marie. 2004. International law and international relations theory: A prospectus. In: Eyal Benvenisti and Moshe Hirsch (Eds.), The Impact of International Law on International Cooperation: Theoretical Perspectives (pp. 16-49). Cambridge University Press. Cambridge, UK.

SUBOTIN, Andriy. 2019. "Future of US hegemony" In: Actual Problems of International Relations. Vol. 139, pp. 4-12.

TELÒ, Mario. 2010. International Relations: A European Perspective, 1st edition. Routledge. London, UK.

VAKARCHUK, Kateryna Vasylivna. 2018. “Argentina's foreign policy in the post-bipolar period" In: Odesa National University Herald. Series: Sociology and Political Sciences. Vol. 23, No. 2(31), pp. 115-127.

VENTURA, Carla Aparecida Arena; CAVALCANTI, Melissa Franchini; DE PAULA, Verônica Angélica Freitas. 2006. "The systems approach to the pluralist theory of international relations: a case study of the European Union” In: Systemic Practice and Action Research. Vol. 19, pp. 475-487.

VOLODINA, Maryna Oleksandrivna. 2012. "NATO in the in the system of dominant foreign policy priorities of the United States and Great Britain in the 1990s" In: Istorychni Zapysky. Vol. 35, pp. 24-32.

WEIBLE, Christopher M; JENKINS-SMITH, Hank C. 2016. The advocacy coalition framework: an approach for the comparative analysis of contentious policy issues. In: B. Guy Peters and Philippe Zittoun (Eds.), Contemporary Approaches to Public Policy (pp. 15-34). Palgrave Macmillan. London, UK.

ZARTMAN, William (Ed.). 2009. Imbalance of Power: US Hegemony and International Order. Lynne Rienner Publishers. Boulder, USA. 

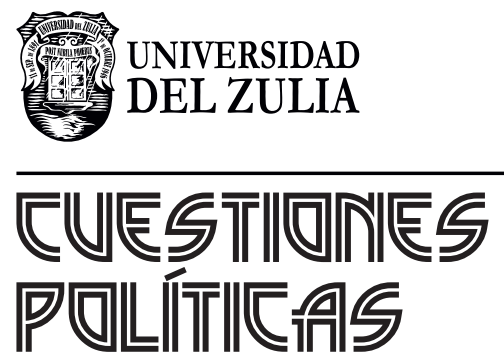

Vol. 39 N $^{\circ} 71$

Esta revista fue editada en formato digital y publicada en diciembre de 2021, por el Fondo Editorial Serbiluz, Universidad del Zulia. Maracaibo-Venezuela 